\title{
Newer Diagnostic and Cost-Effective Ways to Identify Asymptomatic Atrial Fibrillation for the Prevention of Stroke
}

Urvish K. Patel ${ }^{1}$, Preeti Malik ${ }^{2,}{ }^{3}$, Nidhi Patel ${ }^{4}$, Priyadarshee Patel ${ }^{5}$, Neev Mehta ${ }^{6}$, Eseosa Urhoghide ${ }^{7}$, Surya Aedma ${ }^{8}$, Raja Chandra Chakinala 9,10 , Shamik Shah ${ }^{11}$, Kogulavadanan Arumaithurai ${ }^{12}$

1. Neurology and Public Health, Icahn School of Medicine at Mount Sinai, New York, USA 2. Public Health, Icahn School of Medicine at Mount Sinai, New York, USA 3. Neurology, Massachusetts General Hospital, Andover, USA 4. Medicine, Drexel University College of Medicine, Philadelphia, USA 5. Neurology, Drexel University College of Medicine, Philadelphia, USA 6. Epidemiology and Biostatistics, Boston University School of Public Health, Boston, USA 7. Internal Medicine, Hudson Regional Hospital, Secaucus, USA 8. Internal Medicine, Carle Foundation Hospital, Urbana, USA 9. Medicine, Geisinger Commonwealth School of Medicine, Danville, USA 10. Medicine, Guthrie Robert Packer Hospital, Sayre, USA 11. Neurology, Stormont Vail Health, Topeka, USA 12. Neurology, Mayo Clinic Health System, Albert Lea, USA

Corresponding author: Urvish K. Patel, dr.urvish.patel@gmail.com

\begin{abstract}
Atrial fibrillation (Afib) is the most common and underestimated cardiac arrhythmia with a lifetime risk of $>35 \%$ after the age of 55 years and the risk continues to rise exponentially. Afib leads to stasis of blood within the atria allowing clot formation and increasing the risk for systemic embolization leading to strokes. Outcomes due to Afib can improve significantly with appropriate treatment. Thus, the need for convenient, well-tolerated, cost-effective cardiac monitoring for Afib is needed. The study aims to evaluate the various newer devices and compare them with traditional Holter monitoring, keeping diagnostic yield, costeffectiveness, and patients' convenience in mind. Though Holter monitoring is simple and non-expensive, it has major limitations including limited recording capacity, inability for real-time recordings, and inconvenience to patients. Zio Patch (iRhythm Technologies, Inc; San Francisco, CA) and other loop recording devices are patient-friendly, inexpensive, and can offer real-time data for longer days. More prospective studies are needed to evaluate the sensitivity, specificity, and the actual number of patients getting benefits from newer devices by diagnosing Afib sooner and start early prevention therapy.
\end{abstract}

Received 12/17/2020

Review began 12/21/2020 Review ended 12/26/2020 Published 01/02/2021

๑) Copyright 2021 Patel et al. This is an open access article distributed under the terms of the Creative Commons Attribution License CC-BY 4.0., which permits unrestricted use, distribution, and reproduction in any medium, provided the original author and source are credited.
Categories: Cardiology, Neurology, Public Health

Keywords: atrial fibrillation, zio patch, loop recording device, stroke, holter monitoring, cardiac arrhythmia, cardiac rhythm monitoring, ambulatory electrocardiography devices, electrocardiography, acute ischemic stroke

\section{Introduction And Background}

Atrial fibrillation (Afib) is the most common sustained cardiac arrhythmia, with a lifetime risk of 37\% occurrence after the age of 55 years [1]. The causal relation between atrial fibrillation and stroke has been known for many years. Uncoordinated and rapid myocyte activity due to hyperactive electric stimulation from the SA node results in impaired contraction of the atria. This impairment leads to stasis of blood within the atria that allows clot formation to occur, thus increasing the risk for systemic embolization leading to cardio-embolic strokes [2].

Afib has been a major burden on the healthcare system. Though incidence throughout the general population has been relatively stable over time, the prevalence of Afib continues to rise exponentially [3]. Some of the increasing prevalence may be attributable to a modest improvement in Afib-related survival (e.g., three-year mortality rate reduction from $45 \%$ in 1993 to $42 \%$ in 2005), which is related to earlier detection and treatment of underlying conditions such as hypertension, coronary artery disease (CAD), and heart failure (HF) [3]. Afib accounts for 3-4\% of all emergency department visits, with typical symptoms like syncope, palpitations, dizziness attributable to arrhythmias, etc. [4]. There are half a million hospitalizations annually in the United States for which Afib is the primary diagnosis. Afib is estimated to contribute to $>100,000$ deaths per year in the United States. Outpatient cardiac rhythm monitoring is an integral part of the early diagnosis and management of Afib, which is the priority in successful secondary stroke prevention [5]. This stresses the use of ambulatory cardiac monitoring devices for earlier detection of Afib.

The true epidemiological profile of Afib is incomplete and underestimated because a substantial proportion of Afib patients can be asymptomatic or without clinical manifestations ("clinically silent or subclinical Afib” [6]. Clinically silent Afib diagnosed often during routine checkups, leaves difficult decisions for physicians on how to treat and to what extent. Currently, researchers have been focused on clinically silent and asymptomatic Afib which has shown equal outcomes regarding stroke and death. In the most recent data reported by EurObservational Research Programme (EORP)-Atrial Fibrillation Pilot General Registry, 
mortality at one year was more than twofold higher in asymptomatic patients than their symptomatic counterparts and was associated independently with older age and comorbidities [7].

Additionally, undiagnosed Afib can have immense complications and morbidity. Outcomes due to Afib can improve significantly with appropriate treatment, including anticoagulation to prevent systemic embolization and stroke, rhythm, and rate control for the restoration of normal rhythm. Despite guidelines from multiple societies, there is a significant gap in the care of Afib. Earlier and improved methods of detection can allow earlier initiation of appropriate therapies to prevent adverse health outcomes. Furthermore, monitored individuals, compared with non-monitored controls, had higher rates of Afib diagnosis, greater initiation of anticoagulants, but also increased health care resource utilization at one year. Better detection of paroxysmal atrial fibrillation (PAF) by prolonged cardiac monitoring can be expected to improve secondary prevention through optimized secondary preventive regimens, like oral anticoagulation for stroke patients [8]. The improved cost-effectiveness is attributable to the fact that these newly detected patients benefit from anticoagulation therapy to prevent stroke recurrence which in turn saves future costs and reduces the impairment of quality of life.

The need for convenient, well-tolerated, cost-effective cardiac monitoring for Afib is likely to increase as Afib becomes more prevalent [4]. Traditionally monitoring of arrhythmias has been done by a continuous electrocardiogram (ECG) monitor known as a Holter monitor, which is given to patients with a recent history of acute coronary syndrome and daily symptoms such as syncope, dizziness, and palpitations. Continuous ECG monitoring records data such as average heart rate, RR interval, and ST-segment changes for a period of 24-48 hours. Alternatively, in recent years there have been many technological advancements in this field of study. For example, we now have single and double lead ECG that can be placed directly on the chest, smartwatches, and handled devices that pair directly with your phone. These devices have automated algorithms within their specifically designed optical sensors to detect irregularities in pulse to notify the user in real-time of possible atrial fibrillations without the use of electrodes or wires. However, due to its very limited data and accuracy, it still remains unknown when this technology may be used as a primary diagnostic tool in medicine. Lastly, non-invasive continuous monitoring patch such as the Zio Patch (iRhythm Technologies, Inc; San Francisco, CA) is a single-lead ECG monitor that provides up to 14 days of continuous ECG data from a single vector. These devices are single-use, water-resistant, and allow for long term cardiac monitoring. Although this may be a promising technology, larger studies will be required to determine the efficacy of these devices in detecting arrhythmias [9].

Hence, the literature review aims to evaluate the effectiveness of various ambulatory devices in detecting asymptomatic Afib to prevent stroke.

\section{Review}

\section{Types of ambulatory devices}

Atrial fibrillation is the most underestimated cardiac arrhythmia with a lifetime risk of $>35 \%$ after the age of 55 years and the causal relationship between atrial fibrillation and stroke has been known for many years [10]. In addition to atrial fibrillation, arrhythmias such as sinus tachycardia, premature ventricular contractions, and ventricular tachycardia can all cause palpitations. Usually benign, palpitations can be a manifestation of potentially life-threatening conditions, especially if associated with dizziness, nearsyncope, or syncope. Therefore, ambulatory electrocardiogram monitoring is an invaluable tool to assess and establish the diagnosis of a patient's symptoms. There are a variety of possible ambulatory monitors to choose from such as Holter monitors, implantable loop recorders, and external loop recorders. Table 1 showed details on various ambulatory electrocardiography devices and their applications. 


\section{Cureus}

\begin{tabular}{|c|c|c|c|}
\hline $\begin{array}{l}\text { Types of } \\
\text { Device }\end{array}$ & Description & Usefulness & Limitations \\
\hline $\begin{array}{l}\text { Holter } \\
\text { Monitor }\end{array}$ & $\begin{array}{l}\text { For daily or near-daily frequency of symptoms. Has a recording time of } \\
24 \text { hours, } 48 \text { hours, or one week. Available in primary and secondary } \\
\text { care. }\end{array}$ & $\begin{array}{l}\text { Suitable for patients with frequent } \\
\text { symptoms. Less expensive. } \\
\text { Noninvasive and no action needed } \\
\text { from patients. }\end{array}$ & $\begin{array}{l}\text { Limited recording } \\
\text { capacity. }\end{array}$ \\
\hline $\begin{array}{l}\text { External } \\
\text { Loop } \\
\text { Recorders }\end{array}$ & $\begin{array}{l}\text { ECG data can be transmitted continuously over wireless networks to a } \\
\text { remote monitoring system for evaluation. Patients need to activate by } \\
\text { themselves during the onset of symptoms. Available only in specialized } \\
\text { cardiac centers. }\end{array}$ & $\begin{array}{l}\text { Higher likelihood of detecting } \\
\text { arrhythmias due to prolonged } \\
\text { monitoring (in comparison to Holter). } \\
\text { Noninvasive. }\end{array}$ & $\begin{array}{l}\text { Not suitable for } \\
\text { conditions like } \\
\text { syncope when } \\
\text { patients cannot } \\
\text { activate the } \\
\text { device. }\end{array}$ \\
\hline $\begin{array}{l}\text { Implantable } \\
\text { Loop } \\
\text { Recorders }\end{array}$ & $\begin{array}{l}\text { For rare (monthly) frequency of symptoms. Has the longest recording } \\
\text { time for up to } 3 \text { years. Available only in specialized cardiac centers. }\end{array}$ & $\begin{array}{l}\text { Minimally invasive. Both automatic } \\
\text { and patient activated methods are } \\
\text { supported. }\end{array}$ & $\begin{array}{l}\text { Most expensive } \\
\text { among the three } \\
\text { device types. }\end{array}$ \\
\hline Zio Patch & $\begin{array}{l}\text { A single-lead ECG monitor that has no external leads or wires. The } \\
\text { patch is stuck on the patient's left pectoral region and can record a } \\
\text { continuous beat-to-beat ECG, making it useful for monitoring cardiac } \\
\text { rhythm, for up to fourteen days. }\end{array}$ & $\begin{array}{l}\text { Zio Patch has a higher diagnostic } \\
\text { yield to detect Afib and prevention } \\
\text { of strokes per year. This would } \\
\text { result in significant yearly savings in } \\
\text { direct medical costs. }\end{array}$ & $\begin{array}{l}\text { The data of Zio } \\
\text { Patch is analyzed } \\
\text { offline after the } \\
\text { completion of the } \\
\text { monitoring. }\end{array}$ \\
\hline
\end{tabular}

TABLE 1: Types of ambulatory electrocardiography device and their applications.

Holter Monitor

Traditionally, monitoring of arrhythmias has been done by a continuous ECG monitor known as a Holter monitor. The most common monitors allow for continuous registration of three or more leads for 24-48 hours while newer monitors allow for continuous ECG monitoring for up to two weeks [11]. A benefit in extending the time of ECG registration helps improve the diagnostic yield of Holter monitoring, especially for infrequent but recurrent rhythm disturbances [12]. The Holter monitor aids in the detection of arrhythmias and ST-segment changes help to assess the therapeutic efficiency of antiarrhythmic agents and helps to evaluate pacemaker malfunctions [13]. A primary advantage of using Holter monitoring is that it aids in quantifying the real burden of arrhythmia and could help the clinician in making therapeutic decisions for disabling arrhythmias that occur frequently [14]. However, despite this advantage, some limitations include the relatively brief duration of monitoring, limited recording capacity, and inability to transmit real-time data to the attending cardiac unit, and the need for close collaboration between the patient and the healthcare professional [14]. Additionally, these may cause physical discomfort for patients due to the large size of the monitor and electrodes that need to be taped to various areas on the skin that may irritate.

Loop Recorders

Loop recorders are event recorders that work by continually analyzing the ECG and retaining information pertinent to relevant arrhythmias. This is possible through predefined algorithms and registration of the ECG a few minutes prior to the onset of the arrhythmia [14]. These recorders can be activated by the patient when he/she experiences the symptoms and can therefore reliably document a correlation between symptoms and arrhythmia.

Internal Loop Recorders

Implantable loop recorders is a subcutaneous monitoring device used to monitor electrical activity of the heart over an extended period of time, compared to the fixed picture of electrical activity seen with ECGs [15]. These devices can record for up to three years. An implantable loop recorder can store patient-activated episodes, automatically activated episodes or a combination of the two. Some benefits of an implantable loop recorder are that it does not need to be removed during certain activities such as showering or swimming and it can help identify significant cardiac rhythm abnormalities when the patient is sleeping [15]. Additionally, unlike the Holter monitor, an implantable loop recorder has a higher likelihood of detecting arrhythmias due to prolonged monitoring and the ability to detect atrial fibrillation recurrences, as they can be silent and unpredictable [16]. However, it may be affected by false episode detection due to artifacts and they only allow the registration of one lead, rendering the interpretation of the ECG difficult in some cases [14]. Likewise, unlike the Holter monitor, it is far more efficient and reliable at identifying 


\section{Cureus}

abnormal rhythms [15] and data transmission to a distant diagnostic station is simple [14]. This device may be useful for noncompliant patients, as there are no external parts to be worn [17].

External Loop Recorders

External loop recorders can be connected to a belt around the chest, without the need for traditional electrodes, and can monitor the ECG for a maximum of 30 days [18]. Additionally, because this device relies on the patient activating it, it is not suitable for syncope or other conditions in which the patient is unable to activate the device. An advantage of using this device is that ECG data can be transmitted continuously over wireless networks to a remote monitoring system for evaluation.

\section{Zio Patch}

The Zio Patch is a single-lead ECG monitor that has no external leads or wires. The patch adheres to the patient's left pectoral region and can record a continuous beat-to-beat ECG, making it useful for monitoring cardiac rhythm, for up to fourteen days. Similar, to the Holter monitor, the data from the Zio Patch is analyzed offline after the completion of the monitoring. However, the Zio Patch has a higher diagnostic yield than the Holter monitor [19]. The patch provides a high diagnostic yield for arrhythmia because the diagnostic yield of continuous loop-recording decreases rapidly after two weeks of monitoring and monitoring beyond seven days provides only an additional $3.9 \%$ of patients with a diagnosis [20]. In an epidemiologic study done on the older general population, it was found that atrial fibrillation was detected in $4 \%$ of those with no prior history, and $38 \%$ of newly detected atrial fibrillation was first found on days three-14 of monitoring with the Zio Patch [21]. Additionally, a single monitoring episode of 12 days was adequate for estimating the extent of supraventricular and ventricular ectopy [21]. Table 2 described the studies measuring the diagnostic yield of ambulatory ECG monitoring by utilizing newer devices.

\begin{tabular}{|c|c|c|c|c|c|}
\hline $\begin{array}{l}\text { Author, } \\
\text { Year, and } \\
\text { Country }\end{array}$ & Sample Size & $\begin{array}{l}\text { Study Type } \\
\text { and Duration }\end{array}$ & Aim/Objective & Outcomes & Results \\
\hline $\begin{array}{l}\text { Schreiber et } \\
\text { al., } 2013 \\
\text { (USA) [4] }\end{array}$ & 174 & $\begin{array}{l}\text { Multicenter } \\
\text { Prospective } \\
\text { Observational } \\
\text { study; } \\
\text { February } \\
2011 \text { - } \\
\text { February } \\
2012\end{array}$ & $\begin{array}{l}\text { To determine the } \\
\text { diagnostic yield of } \\
\text { Zio Patch and to } \\
\text { determine the value } \\
\text { of prolonged } \\
\text { monitoring of low- } \\
\text { risk discharged ED } \\
\text { patients with } \\
\text { possible cardiac } \\
\text { arrhythmia. }\end{array}$ & $\begin{array}{l}\text { Significant arrhythmias } \\
\text { as ventricular } \\
\text { tachycardia (VT) } \geq 4 \\
\text { beats, paroxysmal } \\
\text { atrial fibrillation (PAF), } \\
\text { supraventricular } \\
\text { tachycardia (SVT) } \geq 4 \\
\text { beats, } \geq 3 \text {-sec pause, } \\
2 \text { nd-degree Mobitz II or } \\
\text { 3rd degree AV block, or } \\
\text { symptomatic } \\
\text { bradycardia. Serious } \\
\text { arrhythmias were } \\
\text { defined as VT }>120 \text { for } \\
30 \text { seconds, Complete } \\
\text { or 3rd-degree heart } \\
\text { block, symptomatic } \\
\text { second-degree heart } \\
\text { block, type II, pause }>6 \\
\text { seconds, and } \\
\text { symptomatic } \\
\text { bradycardia }<40 \text { beats } \\
\text { per minute for }>30 \\
\text { seconds. }\end{array}$ & $\begin{array}{l}\text { The average age } 52.2( \pm 21.0) \text { years and } 55 \% \\
\text { were female. The most common indications } \\
\text { for device placement were palpitations } \\
(44.8 \%) \text {, syncope }(24.1 \%) \text {, and dizziness } \\
(6.3 \%) .47 .7 \% \text { had } \geq 1 \text { arrhythmia and } 9.8 \% \\
\text { were symptomatic at the time of their } \\
\text { arrhythmia. } 5.2 \% \text { had } \geq 2 \text { arrhythmias. } 7 \\
\text { patients required immediate physician } \\
\text { notification for serious arrhythmias. } 93 \\
(53.4 \%) \text { of symptomatic patients did not have } \\
\text { any arrhythmia during their triggered events. } \\
\text { The overall diagnostic yield was } 63.2 \% \text {. }\end{array}$ \\
\hline $\begin{array}{l}\text { Gladstone et } \\
\text { al., } 2015\end{array}$ & 237 & $\begin{array}{l}\text { Multicenter } \\
\text { randomized }\end{array}$ & $\begin{array}{l}\text { To predict which } \\
\text { cryptogenic stroke } \\
\text { or TIA patients have } \\
\text { the highest } \\
\text { probability of } \\
\text { subclinical Afib. } \\
\text { Data from the } \\
\text { EMBRACE trial was } \\
\text { used to investigate } \\
\text { the association }\end{array}$ & $\begin{array}{l}\text { Primary: Detection of } \\
\geq 1 \text { episode of atrial } \\
\text { fibrillation or flutter } \\
\text { lasting } \geq 30 \text { s by } 30 \text {-day } \\
\text { ECG monitoring or } \\
\text { clinically within } 90 \text { days } \\
\text { post-randomization. } \\
\text { Secondary: Afib } \geq 30 \mathrm{~s}\end{array}$ & $\begin{array}{l}\text { Primary: Median baseline APB count was } 66 \\
\text { (IQR, 18-309) in the entire cohort, higher in } \\
\text { patients who were subsequently found to } \\
\text { have Afib ( } 629 \text { beats } / 24 \mathrm{~h}\{\mathrm{IQR}, 142-1973\} \text { ) } \\
\text { compared with those without Afib ( } 45 \\
\text { beats/24 } \mathrm{h}\{\mathrm{IQR}, 14-250\} \text { ); } p<0.001 \text {. } \\
\text { Secondary: Afib } \geq 30 \text { s on the } 30 \text {-day ECG } \\
\text { monitor alone ( } p<0.0001 \text { ) and the more } \\
\text { robust outcome of Afib } \geq 2.5 \text { minutes on } 30 \text { - } \\
\text { day ECG ( } p=0.0005 \text { ), and for Afib detection } \\
\text { by any means at } 2 \text { years ( } p=0.0027 \text { ). Overall, }\end{array}$ \\
\hline
\end{tabular}




\section{Cureus}

\begin{tabular}{|c|c|c|c|c|c|}
\hline (USA) [22] & & $\begin{array}{l}\text { controlled } \\
\text { trial. }\end{array}$ & $\begin{array}{l}\text { between Holter- } \\
\text { detected atrial } \\
\text { ectopic activity, on } \\
\text { the subsequent } \\
\text { detection of Afib by } \\
\text { 30-day ECG } \\
\text { monitoring, and } \\
\text { during clinical } \\
\text { follow-up at } 90 \text { days } \\
\text { and } 2 \text { years. }\end{array}$ & $\begin{array}{l}\text { detected by } 30 \text {-day } \\
\text { ECG, Afib } \geq 2.5 \text { minutes } \\
\text { detected by } 30 \text {-day } \\
\text { ECG, and Afib detected } \\
\text { by any means within } 2 \\
\text { years of clinical follow- } \\
\text { up. }\end{array}$ & $\begin{array}{l}\text { the } 90 \text {-day Afib detection rate in the } \\
\text { intervention group was } 16 \% \text { but it was highly } \\
\text { dependent on the baseline APB count: the } \\
\text { predicted probability of Afib was } 7 \% \text { to } 9 \% \text { in } \\
\text { patients with }<100 \mathrm{APBs} / 24 \mathrm{~h}, 9 \% \text { to } 24 \% \text { in } \\
\text { those with } 100 \text { to } 499 \mathrm{APBs} / 24 \mathrm{~h}, 25 \% \text { to } 37 \% \\
\text { in those with } 500 \text { to } 999 \mathrm{APBs} / 24 \mathrm{~h}, 37 \% \text { to } \\
40 \% \text { in those with } 1000 \text { to } 1499 \mathrm{APBs} / 24 \mathrm{~h} \text {, } \\
\text { and it reached a plateau } \approx 40 \% \text { in those with } \\
\geq 1500 \mathrm{APBs} / 24 \mathrm{~h} \text {. }\end{array}$ \\
\hline $\begin{array}{l}\text { Kaura et al., } \\
2019 \text { (UK) } \\
{[23]}\end{array}$ & $\begin{array}{l}\text { Patch-based } \\
\text { monitoring } \\
\text { group:56. Holter } \\
\text { monitoring } \\
\text { group:60 }\end{array}$ & $\begin{array}{l}\text { Open-label } \\
\text { randomized } \\
\text { controlled } \\
\text { trial February } \\
2016- \\
\text { February } \\
2017 \text { for } 90 \\
\text { days }\end{array}$ & $\begin{array}{l}\text { Compare 14-day } \\
\text { ECG monitoring } \\
\text { patch (Zio Patch) } \\
\text { with short-duration } \\
\text { Holter monitoring } \\
\text { for the detection of } \\
\text { PAF. }\end{array}$ & $\begin{array}{l}\text { Primary: Detection of } \\
\text { one or more episodes } \\
\text { of ECG-documented } \\
\text { PAF lasting at least } 30 \\
\text { s within } 90 \text { days in } \\
\text { each of the study arms. } \\
\text { Secondary: PAF lasting } \\
\text { at least } 30 \text { s within } \\
28 \text { days in each of the } \\
\text { study arms and PAF } \\
\text { lasting at least } 30 \mathrm{~s} \\
\text { detected on the patch- } \\
\text { based monitoring or } \\
\text { short-duration Holter } \\
\text { monitor within } 90 \text { days } \\
\text { in patients who } \\
\text { underwent both ECG } \\
\text { monitoring strategies } \\
\text { and A budget impact } \\
\text { analysis from the } \\
\text { healthcare perspective } \\
\text { was performed }\end{array}$ & $\begin{array}{l}\text { Primary: The rate of detection of PAF at } 90 \\
\text { days was } 16.3 \% \text { in the patch-based } \\
\text { monitoring group (seven patients) compared } \\
\text { to } 2.1 \% \text { in the short-duration Holter } \\
\text { monitoring group ( } 1 \text { patient), with an odds } \\
\text { ratio of } 8.9 \text { ( } 95 \% \text { Cl: } 1.1-76.0 ; p=0.026 \text { ) } \\
\text { Secondary: An economic model } \\
\text { demonstrated that implementation of the Zio } \\
\text { Patch service would result in } 10.8 \text { more } \\
\text { strokes avoided per year compared to } \\
\text { current practice with Holter monitoring with } \\
\text { an associated yearly saving in direct medical } \\
\text { costs of } £ 113,630 \text {, increasing to } £ 162,491 \\
\text { over } 5 \text { years. }\end{array}$ \\
\hline $\begin{array}{l}\text { Kamel et al., } \\
2013 \\
\text { (USA) [24] }\end{array}$ & 40 & $\begin{array}{l}\text { Pilot } \\
\text { randomized } \\
\text { controlled } \\
\text { trial. October } \\
29,2009 \text {-May } \\
24,201 ; 21 \\
\text { days with } \\
\text { follow up at } 3 \\
\text { months and } 1 \\
\text { year }\end{array}$ & $\begin{array}{l}\text { To establish the } \\
\text { safety and feasibility } \\
\text { of Cardionet Mobile } \\
\text { Cardiac Outpatient } \\
\text { Telemetry } 20 \\
\text { patients wear the for } \\
21 \text { days and } 20 \\
\text { patients to get } \\
\text { routine care. }\end{array}$ & $\begin{array}{l}\text { Primary: primary } \\
\text { feasibility outcomes } \\
\text { were enrollment of } 40 \\
\text { patients in } 2 \text { years, } \\
\text { completion of assigned } \\
\text { monitoring in } \geq 70 \% \text { of } \\
\text { patients, and full } \\
\text { follow-up for } \geq 90 \% \text { of } \\
\text { patients. The primary } \\
\text { safety outcome was } \\
\text { any adverse event } \\
\text { resulting directly from } \\
\text { the use of the cardiac } \\
\text { monitoring device. } \\
\text { Secondary: New } \\
\text { diagnoses of Afib } \\
\text { within } 3 \text { months and } 1 \\
\text { year }\end{array}$ & $\begin{array}{l}64 \% \text { Overall compliance. No patient } \\
\text { diagnosed with Afib, } 2 \text { patients had brief } \\
\text { episodes ( }<10 \text { seconds) of atrial tachycardia, } \\
\text { and } 2 \text { patients had non-sustained ventricular } \\
\text { tachycardia. No serious adverse event } \\
\text { occurred that was attributable to the } \\
\text { monitoring intervention. }\end{array}$ \\
\hline $\begin{array}{l}\text { Baturova et } \\
\text { al., 2016 } \\
\text { (USA) [25] }\end{array}$ & 110 & $\begin{array}{l}\text { Post-hoc } \\
\text { analysis from } \\
\text { a previous } \\
\text { prospective } \\
\text { case-control } \\
\text { study. }\end{array}$ & $\begin{array}{l}\text { Investigate clinical, } \\
\text { ECG, and TTE } \\
\text { characteristics } \\
\text { associated with } \\
\text { paroxysmal Afib in } \\
\text { ischemic stroke } \\
\text { patients. }\end{array}$ & $\begin{array}{l}\text { To assess predictors of } \\
\text { paroxysmal atrial } \\
\text { fibrillation using non- } \\
\text { invasive surface ECG } \\
\text { and transthoracic } \\
\text { echocardiography to } \\
\text { select candidates for } \\
\text { atrial fibrillation } \\
\text { screening }\end{array}$ & $\begin{array}{l}\text { Primary: Atrial fibrillation history was } \\
\text { independently associated with vascular } \\
\text { diseases (OR: } 4.10 ; 95 \% \mathrm{Cl}: 1.32- \\
\text { 12.78; } \mathrm{p}=0.015 \text { ), } \mathrm{P} \text { wave terminal force in lead } \\
\mathrm{V} 1>40 \mathrm{~mm}^{*} \mathrm{~ms} \text { (OR: } 4.04 ; 95 \% \mathrm{Cl}: 1.34- \\
12.14 ; \mathrm{p}=0.013 \text { ) and left atrial volume index } \\
\text { (OR: } 1.08 ; 95 \% \mathrm{Cl}: 1.03-1.13 ; \mathrm{p}=0.002 \text { ). Left } \\
\text { atrial volume index remained an independent } \\
\text { predictor of atrial fibrillation detected after } \\
\text { stroke (OR: } 1.09 ; 95 \% \mathrm{Cl}: 1.02-1.16 ; \mathrm{p}=0.017 \text { ). }\end{array}$ \\
\hline & & & To eva & \multicolumn{2}{|l|}{$\begin{array}{l}\text { Primary: The primary } \\
\text { endpoint was time to } \\
\text { diagnosis of Afib. Afib }\end{array}$} \\
\hline
\end{tabular}




\section{Cureus}

\begin{tabular}{|c|c|c|c|c|c|}
\hline $\begin{array}{l}\text { Halcox et } \\
\text { al., } \\
2017(\text { UK)[26] }\end{array}$ & $\begin{array}{l}1001 \\
\text { patiensiECG:500 } \\
\text { Routine care: } \\
501\end{array}$ & $\begin{array}{l}\text { Randomized } \\
\text { controlled } \\
\text { trial for } 12 \\
\text { months }\end{array}$ & $\begin{array}{l}\text { efficacy of AliveCor } \\
\text { Kardia device (a } \\
\text { smartphone/tablet- } \\
\text { based single-lead } \\
\text { electrocardiographic } \\
\text { capture system) vs } \\
\text { routine clinical care } \\
\text { (RC) in patients }>65 \\
\text { years of age with } \geq 1 \\
\text { additional stroke } \\
\text { risk factor. }\end{array}$ & $\begin{array}{l}\text { was defined as a } 30- \\
\text { second iECG recording } \\
\text { with irregular rhythm } \\
\text { without } p \text { waves } \\
\text { Secondary: Incidence } \\
\text { of Adverse vascular } \\
\text { events which were } \\
\text { either reported at the } \\
\text { time of event or were } \\
\text { identified by telephone } \\
\text { at } 12,32 \text {, and } 52 \\
\text { weeks, with } \\
\text { confirmation from } \\
\text { source clinical records. }\end{array}$ & $\begin{array}{l}\text { Primary: } 74 \% \text { overall compliance. } 19 \text { patients } \\
\text { in the iECG group were diagnosed with Afib } \\
\text { over the } 12-\text {-month study period vs } 5 \text { in the } \\
\text { RC arm (HR: } 3.9 ; 95 \% \text { Cl: } 1.4-10.4 ; p=0.007 \text { ) } \\
\text { at a cost per Afib diagnosis of } \$ 10780 \\
\text { (£8255). Secondary: There was a similar } \\
\text { number of stroke/transient ischemic } \\
\text { attack/systemic embolic events ( } 6 \text { vs } 10 \text {, } \\
\text { iECG vs RC; HR:0.61; } 95 \% \text { Cl: } 0.22-1.69 ; \\
p=0.34 \text { ). }\end{array}$ \\
\hline $\begin{array}{l}\text { Reed et al., } \\
2018 \\
\text { (Scotland) } \\
{[27]}\end{array}$ & 86 & $\begin{array}{l}\text { Prospective } \\
\text { pilot study. } \\
\text { November } 17 \text {, } \\
\text { 2015-June } \\
16,2017\end{array}$ & $\begin{array}{l}\text { This study } \\
\text { investigates } \\
\text { diagnostic yield, } \\
\text { event prevalence, } \\
\text { patient satisfaction } \\
\text { and compliance, } \\
\text { and influence on } \\
\text { resource utilization } \\
\text { of an ambulatory } \\
\text { patch monitor (Zio } \\
\text { XT monitor). }\end{array}$ & $\begin{array}{l}\text { The primary endpoint } \\
\text { was symptomatic } \\
\text { significant arrhythmia } \\
\text { at } 90 \text {-day follow-up. }\end{array}$ & $\begin{array}{l}\text { 90-day diagnostic yield for symptomatic } \\
\text { significant arrhythmia was } 10.5 \%(95 \% \mathrm{Cl} \text { : } \\
\text { 4.0-16.9; } 9 \text { of } 86 \text { ) vs } 2.0 \% \text { (95\% Cl: } 0.9-3.1 ; 12 \\
\text { of } 603) \text { in the comparator group. } 24 \text { patients } \\
(27.9 \%) \text { had a significant arrhythmia (five } \\
\text { serious); } 26 \text { patients ( } 30.2 \% \text { ) had serious } \\
\text { outcomes (major adverse cardiac event } \\
\text { and/or death). The patch would significantly } \\
\text { reduce requirements for standard outpatient } \\
\text { ambulatory ECG monitoring. } 56 \text { of } 76 \\
\text { returned patches had a diagnostic finding } \\
\text { within } \pm 45 \text { s of a triggered/diary event }(73.7 \% \\
\text { diagnostic utility; } 95 \% \text { Cl: } 63.7-83.6) ; 34 \text { of } 56 \\
\text { (61\%) for sinus rhythm or ectopic beats only }\end{array}$ \\
\hline $\begin{array}{l}\text { Pradhan et. } \\
\text { al, 2019 } \\
\text { (USA) [28] }\end{array}$ & 363 & $\begin{array}{l}\text { Single-center } \\
\text { Retrospective } \\
\text { study. } \\
\text { October } 2014 \\
\text { to February } \\
2016\end{array}$ & $\begin{array}{l}\text { To describe the } \\
\text { duration of ZIO XT } \\
\text { Patch use by age } \\
\text { and to compare its } \\
\text { time to arrhythmia } \\
\text { detection with the } \\
\text { Holter monitor in a } \\
\text { pediatric population. }\end{array}$ & $\begin{array}{l}\text { Demographics, as well } \\
\text { as diagnostic data } \\
\text { including duration of } \\
\text { ZIO use, time to the } \\
\text { first arrhythmia, and } \\
\text { arrhythmias detected. } \\
\text { SVT was defined as } 3 \\
\text { or more consecutive } \\
\text { ectopic beats arising } \\
\text { from proximal to the } \\
\text { bundle of His. VT was } \\
\text { defined as } 3 \text { or more } \\
\text { consecutive ectopic } \\
\text { beats arising distal to } \\
\text { the bundle of His. }\end{array}$ & $\begin{array}{l}\text { The median age was significantly different } \\
\text { between the ZIO ( } 12.7 \text { years) and Holter } \\
\text { ( } 4.9 \text { years) within } 72 \text { hours }(n=15) \text {. The } \\
\text { majority of arrhythmias }(57 \%) \text { detected by } \\
\text { ZIO were after } 24 h \text { ( } p<0.0001) \text {. All } \\
\text { arrhythmias detected by the Holter monitor } \\
\text { occurred within } 24 h \text { ( } p<0.0001) \text {. }\end{array}$ \\
\hline \multirow[t]{2}{*}{$\begin{array}{l}\text { Turakhia et. } \\
\text { al, 2013 } \\
\text { (USA) [29] }\end{array}$} & 26,751 & $\begin{array}{l}\text { Cross- } \\
\text { sectional } \\
\text { study. } \\
\text { January 1, } \\
\text { 2011- } \\
\text { December 31, } \\
2011\end{array}$ & $\begin{array}{l}\text { To evaluate } \\
\text { compliance, } \\
\text { analyzable signal } \\
\text { time, the interval to } \\
\text { arrhythmia } \\
\text { detection, and } \\
\text { diagnostic yield of } \\
\text { the Zio Patch. }\end{array}$ & $\begin{array}{l}\text { Arrhythmia first } \\
\text { occurrence, first } \\
\text { symptomatic } \\
\text { occurrence (if occurring } \\
45 \text { seconds before or } \\
\text { after patient triggering), } \\
\text { and longest duration. } \\
\text { The total wear time } \\
\text { was calculated from } \\
\text { the point of activation } \\
\text { to the point of the last } \\
\text { recorded analyzable } \\
\text { signal. }\end{array}$ & $\begin{array}{l}\text { The mean wear time was } 7.6 \pm 3.6 \text { days, and } \\
\text { the median analyzable time was } 99 \% \text { of the } \\
\text { total wear time. Arrhythmias were detected in } \\
60.3 \% \text { of patients, } 46 \% \text { had single } \\
\text { arrhythmia, } 11.5 \% \text { had multiple. } 7.5 \% \text { had } \\
\text { chronic Afib. } 29.9 \% \text { had their first arrhythmia } \\
\text { and } 51.1 \% \text { had their first symptom-triggered } \\
\text { arrhythmia after the initial } 48 \text {-hour period. } \\
\text { Compared with the first } 48 \text { hours of } \\
\text { monitoring, the overall diagnostic yield for } \\
\text { Zio Patch was greater for any arrhythmia } \\
\text { (62.2\% vs } 43.9 \% ; p<0.0001) \text { and for any } \\
\text { symptomatic arrhythmia }(9.7 \% \text { vs } 4.4 \% ; \\
\text { p<0.0001). }\end{array}$ \\
\hline & & Rando & To determine the & $\begin{array}{l}\text { Primary: Incidence of a } \\
\text { new diagnosis of Afib } \\
\text { at } 4 \text { months among } \\
\text { those randomized to } \\
\text { immediate monitoring } \\
\text { vs delayed monitoring. } \\
\text { Secondary: New Afib }\end{array}$ & New Afib was identified by 4 months in $3.9 \%$ \\
\hline
\end{tabular}




\section{Cureus}

\begin{tabular}{|c|c|c|c|c|c|}
\hline $\begin{array}{l}\text { Steinhubl et. } \\
\text { al, 2018 } \\
\text { (USA) [30] }\end{array}$ & 2659 & $\begin{array}{l}\text { clinical trial } \\
\text { and } \\
\text { prospective } \\
\text { matched } \\
\text { observational } \\
\text { cohort study. } \\
\text { November } 17 \text {, } \\
2015- \\
\text { October 4, } \\
2016\end{array}$ & $\begin{array}{l}\text { effect of a self- } \\
\text { applied wearable } \\
\text { ECG patch in } \\
\text { detecting Afib and } \\
\text { the clinical } \\
\text { consequences } \\
\text { associated with } \\
\text { such a detection } \\
\text { strategy. }\end{array}$ & $\begin{array}{l}\text { diagnosis at } 1 \text { year in } \\
\text { the combined actively } \\
\text { monitored groups vs } \\
\text { matched observational } \\
\text { controls. Other: New } \\
\text { prescriptions for } \\
\text { anticoagulants and } \\
\text { health care utilization } \\
\text { (outpatient cardiology } \\
\text { visits, primary care } \\
\text { visits, or Afib-related } \\
\text { emergency department } \\
\text { visits and } \\
\text { hospitalizations) at } 1 \\
\text { year. }\end{array}$ & $\begin{array}{l}\text { of the immediate group vs } 0.9 \% \text { in the } \\
\text { delayed group (AD: } 3.0 \% \text {; } 95 \% \text { Cl: } 1.8-4.1 \% \text { ). } \\
\text { At 1-year, new Afib diagnosed in } 109 \\
\text { monitored and } 81 \text { unmonitored. Active } \\
\text { monitoring was associated with increased } \\
\text { initiation of anticoagulants (AD: } 2.0 ; 95 \% \mathrm{Cl} \text { : } \\
1.9-2.2 \text { ), outpatient cardiology visits (AD: } 7.5 \text {; } \\
95 \% \mathrm{Cl}: 7.2-7.9 \text { ), and primary care visits (AD: } \\
0.9 ; 95 \% \text { Cl: } 0.4-1.5 \text { ). There was no difference } \\
\text { in Afib-related ED visits and hospitalizations. }\end{array}$ \\
\hline $\begin{array}{l}\text { Rosenberg } \\
\text { et. al, 2013 } \\
\text { (USA) [9] }\end{array}$ & 74 & $\begin{array}{l}\text { Single-center } \\
\text { Prospective } \\
\text { study. April } \\
27,2011 \text {-May } \\
25,2012\end{array}$ & $\begin{array}{l}\text { To determine if Zio } \\
\text { Patch would be well } \\
\text { tolerated and } \\
\text { function as well as a } \\
\text { Holter monitor in the } \\
\text { first } 24 \text { hours of use } \\
\text { in terms of the } \\
\text { detection of Afib } \\
\text { and other } \\
\text { arrhythmias. To } \\
\text { determine if } \\
\text { additional days of } \\
\text { monitoring would be } \\
\text { tolerated and yield } \\
\text { meaningful clinical } \\
\text { findings. }\end{array}$ & $\begin{array}{l}\text { Significant arrhythmias } \\
\text { were defined as Afib or } \\
\text { atrial flutter, other } \\
\text { supraventricular } \\
\text { tachycardias (not } \\
\text { including Afib or atrial } \\
\text { flutter) for }>4 \text { beats, } \\
\text { sustained ventricular } \\
\text { tachycardia ( }>4 \text { beats), } \\
\text { junctional rhythm, } \\
\text { sinus bradycardia ( }<50 \\
\text { beats/min), and } \\
\text { complete or high-grade } \\
\text { heart block. }\end{array}$ & $\begin{array}{l}\text { The Zio Patch was well tolerated, with a } \\
\text { mean monitoring period of } 10.8 \pm 2.8 \text { days. } \\
\text { During the first } 24 \text { hours period, there was a } \\
\text { significant difference in the mean Afib burden } \\
\text { estimated by the Zio Patch and the Holter } \\
\text { monitor ( } p<0.0001) \text {. Afib events were } \\
\text { identified in } 18 \text { additional individuals, and the } \\
\text { documented pattern of Afib (persistent or } \\
\text { paroxysmal) changed in } 21 \text { patients after } \\
\text { Zio Patch monitoring. As a result of the } \\
\text { findings from the Zio Patch, } 28.4 \% \text { of } \\
\text { patients had a change in their clinical } \\
\text { management. }\end{array}$ \\
\hline $\begin{array}{l}\text { Kaura et. al, } \\
2019 \text { (UK) } \\
\text { [31] }\end{array}$ & 120 & $\begin{array}{l}\text { Open-label } \\
\text { randomized } \\
\text { controlled } \\
\text { trial. February } \\
2016- \\
\text { February } \\
2017\end{array}$ & $\begin{array}{l}\text { To comparing a 14- } \\
\text { day Zio Patch, with } \\
\text { Holter monitoring } \\
\text { for the detection of } \\
\text { PAF. }\end{array}$ & $\begin{array}{l}\text { The primary outcome } \\
\text { was the detection of } \\
\text { one or more episodes } \\
\text { of ECG-documented } \\
\text { PAF lasting at least } 30 \\
\mathrm{~s} \text { within } 90 \text { days in } \\
\text { each of the study arms. }\end{array}$ & $\begin{array}{l}\text { The rate of detection of PAF at } 90 \text { days was } \\
16.3 \% \text { in Zio Patch compared to } 2.1 \% \text { in the } \\
\text { short-duration Holter monitoring group (OR: } \\
8.9 ; 95 \% \mathrm{Cl}: 1.1-76.0 ; \mathrm{p}=0.026 \text { ). Zio Patch } \\
\text { service would result in } 10.8 \text { more strokes } \\
\text { avoided per year compared to current } \\
\text { practice with Holter monitoring with an } \\
\text { associated yearly saving in direct medical } \\
\text { costs of } £ 113,630 \text {, increasing to } £ 162,491 \\
\text { over } 5 \text { years. }\end{array}$ \\
\hline
\end{tabular}

\section{TABLE 2: Studies measuring diagnostic yield of ambulatory ECG monitoring.}

VT: ventricular tachycardia, PAF: paroxysmal atrial fibrillation, SVT: supraventricular tachycardia, Afib: atrial fibrillation, APB: atrial premature beat, TTE: transthoracic echocardiography, ECG: electrocardiogram, AD: absolute difference, OR: odds ratio, IQR: interquartile range

\section{Cost-effectiveness}

Early detection and timely treatment of arrhythmias are important to reduce the burden of cardiac disease and lower healthcare costs. ECG monitoring beyond the 24-48-hours Holter monitor can improve the detection of arrhythmias, however, prolonged monitoring beyond eight to 14 days is generally not costeffective $[4,9,22-31]$. Therefore, wearable patch monitors such as the Zio Patch, that record at least eight days of ECG data are cost-effective alternatives to the traditional Holter monitors and loop recorders.

In an economic model derived from a randomized controlled study comparing the efficacy of a Holter monitor to the Zio Patch for the detection of PAF after a transient ischemic attack/ischemic stroke, it was found that the implementation of the Zio Patch would prevent 10.8 more strokes per year when compared to the current practice with Holter monitoring [23]. This would result in a yearly saving in direct medical costs of $£ 113,630$ (\$146,963), increasing to $£ 162,491$ (\$210,157) over five years [23]. Additionally, Brignole et al. noted that while the 24-48 hours Holter monitor has a relatively low set-up cost, it is expensive in terms of cost per diagnosis [32]. Arnold et al. also state that although it is fairly common to repeat Holter monitoring after the first Holter procedure due to inconclusive results, repeat monitoring did not yield a diagnosis, and 
patients continued to experience clinical events that led to substantial health costs [33]. In another study comparing the efficacy of the Holter monitor to a 14-day adhesive patch, it was found that the adhesive patch monitor detected 96 arrhythmia events compared with 61 arrhythmia events by the Holter monitor $(p<0.001)$ [34]. This emphasizes the importance of effective diagnosis and treatment in reducing healthcare costs, morbidity, and mortality associated with cardiac arrhythmias. Additionally, the study comparing seven-day-Holter monitoring (7-d-Holter) to a standard 24-hour-Holter to detect PAF, it was found that the seven-day-Holter in patients with cerebral ischemia is cost-effective [8]. The costeffectiveness is due to the increased detection which leads to the implementation of improved antithrombotic regimes that work to avoid recurrent strokes and decrease quality of life impairment. This also emphasizes the role that a seven to 14-day monitoring modality, such as the Zio Patch, can play in reducing healthcare costs.

In addition to the increased healthcare costs associated with the use of the Holter monitor, studies have found that there is an increased cost in monitoring periods beyond two weeks. For instance, the costs can range up to $\$ 5832$ per new diagnosis versus a $\$ 98$ cost per patient diagnosis over an initial seven days and $\$ 576$ over a 14-day period [34]. Therefore, the Zio Patch is likely to achieve a reasonable diagnostic yield compared to loop recorders which typically monitor from up to a month to three years.

\section{Conclusions}

Our knowledge of the true ("clinically silent or subclinical Afib") prevalence of Afib is underestimated and represents the tip of the iceberg. Holter monitoring is helpful yet limited by duration, recording capacity, and inability to transmit real-time data. External loop recorder and Zio Patch are better alternatives due to convenient and accurate recording and portability. These newer devices would result in more stroke prevention per year and are more cost-effective in comparison with Holter monitoring. Although these newer devices are proven effective to identify Afib, more prospective studies should be planned to evaluate sensitivity, specificity, and the role of these devices to begin early management in the direction of stroke prevention, and patients' satisfaction.

\section{Additional Information \\ Disclosures}

Conflicts of interest: In compliance with the ICMJE uniform disclosure form, all authors declare the following: Payment/services info: All authors have declared that no financial support was received from any organization for the submitted work. Financial relationships: All authors have declared that they have no financial relationships at present or within the previous three years with any organizations that might have an interest in the submitted work. Other relationships: All authors have declared that there are no other relationships or activities that could appear to have influenced the submitted work.

\section{References}

1. Weng L-C, Preis SR, Hulme OL, et al.: Genetic predisposition, clinical risk factor burden, and lifetime risk of atrial fibrillation. Circulation. 2018, 137:1027-1038. 10.1161/CIRCULATIONAHA.117.031431

2. Harvey E, Levine S: A study of uninfected mural thrombi of the heart . Am J Med Sci. 1930, 180:365-371. 10.1097/00000441-193009000-00006

3. Piccini JP, Hammill BG, Sinner MF, et al.: Incidence and prevalence of atrial fibrillation and associated mortality among medicare beneficiaries. Circ Cardiovasc Qual Outcomes. 2012, 5:85-93. 10.1161/CIRCOUTCOMES.111.962688

4. Schreiber D, Sattar A, Drigalla D, Higgins S: Ambulatory cardiac monitoring for discharged emergency department patients with possible cardiac arrhythmias. West J Emerg Med. 2014, 15:194-198. 10.5811/westjem.2013.11.18973

5. Wolf PA, Abbott RD, Kannel WB: Atrial fibrillation as an independent risk factor for stroke: the Framingham Study. Stroke. 1991, 22:983-988. 10.1161/01.STR.22.8.983

6. Boriani G, Pettorelli D: Atrial fibrillation burden and atrial fibrillation type: clinical significance and impact on the risk of stroke and decision making for long-term anticoagulation. Vascul Pharmacol. 2016, 83:26-35. 10.1016/j.vph.2016.03.006

7. Boriani G, Laroche C, Diemberger I, et al.: Asymptomatic atrial fibrillation: clinical correlates, management, and outcomes in the EORP-AF Pilot General Registry. Am J Med. 2015, 128:509-518. 10.1016/j.amjmed.2014.11.026

8. Mayer F, Stahrenberg R, Gröschel K, et al.: Cost-effectiveness of 7-day-Holter monitoring alone or in combination with transthoracic echocardiography in patients with cerebral ischemia. Clin Res Cardiol. 2013, 102:875-884. 10.1007/s00392-013-0601-2

9. Rosenberg MA, Samuel M, Thosani A, Zimetbaum PJ: Use of a noninvasive continuous monitoring device in the management of atrial fibrillation: a pilot study. Pacing Clin Electrophysiol. 2013, 36:328-333. 10.1111/pace. 12053

10. Marini C, De Santis F, Sacco S, Russo T, Olivieri L, Totaro R, Carolei A: Contribution of atrial fibrillation to incidence and outcome of ischemic stroke: results from a population-based study. Stroke. 2005, 36:11151119. 10.1161/01.STR.0000166053.83476.4a

11. Zimetbaum P, Goldman A: Ambulatory arrhythmia monitoring: choosing the right device . Circulation. 2010, 122:1629-1636. 10.1161/circulationaha.109.925610

12. Paudel B, Paudel K: The diagnostic significance of the holter monitoring in the evaluation of palpitation . J 
Clin Diagn Res. 2013, 7:480-483. 10.7860/jcdr/2013/4923.2802

13. Kunkes SH, Pichard A, Meller J, Gorlin R, Herman MV, Kupersmith J: Use of the ambulatory ECG to diagnose coronary artery disease. J Electrocardiol. 1980, 13:341-346. 10.1016/s0022-0736(80)80085-9

14. Galli A, Ambrosini F, Lombardi F: Holter monitoring and loop recorders: from research to clinical practice . Arrhythm Electrophysiol Rev. 2016, 5:136-143. 10.15420/aer.2016.17.2

15. Vilcant V, Kousa O, Hai O: Implantable Loop Recorder. StatPearls, Treasure Island, FL; 2020.

16. Bisignani A, De Bonis S, Mancuso L, Ceravolo G, Bisignani G: Implantable loop recorder in clinical practice . J Arrhythm. 2019, 35:25-32. 10.1002/joa3.12142

17. Giada F, Bertaglia E, Reimers B, Noventa D, Raviele A: Current and emerging indications for implantable cardiac monitors. Pacing Clin Electrophysiol. 2012, 35:1169-1178. 10.1111/j.1540-8159.2012.03411.x

18. Gladstone DJ, Spring M, Dorian P, et al.: Atrial fibrillation in patients with cryptogenic stroke . N Engl J Med. 2014, 370:2467-2477. 10.1056/NEJMoa1311376

19. Barrett PM, Komatireddy R, Haaser S, et al.: Comparison of 24-hour Holter monitoring with 14-day novel adhesive patch electrocardiographic monitoring. Am J Med. 2014, 127:95. 10.1016/j.amjmed.2013.10.003

20. Zimetbaum PJ, Kim KY, Josephson ME, Goldberger AL, Cohen DJ: Diagnostic yield and optimal duration of continuous-loop event monitoring for the diagnosis of palpitations. A cost-effectiveness analysis. Ann Intern Med. 1998, 128:890-895. 10.7326/0003-4819-128-11-199806010-00002

21. Heckbert SR, Austin TR, Jensen PN, Floyd JS, Psaty BM, Soliman EZ, Kronmal RA: Yield and consistency of arrhythmia detection with patch electrocardiographic monitoring: the multi-ethnic study of atherosclerosis. J Electrocardiol. 2018, 51:997-1002. 10.1016/j.jelectrocard.2018.07.027

22. Gladstone DJ, Dorian P, Spring M, et al.: Atrial premature beats predict atrial fibrillation in cryptogenic stroke. Stroke. 2015, 46:936-941. 10.1161/STROKEAHA.115.008714

23. Kaura A, Sztriha L, Chan FK, Aeron-Thomas J, Gall N, Piechowski-Jozwiak B, Teo JT: Early prolonged ambulatory cardiac monitoring in stroke (EPACS): an open-label randomised controlled trial. Eur J Med Res. 2019, 24:25. 10.1186/s40001-019-0383-8

24. Kamel H, Navi BB, Elijovich L, et al.: Pilot randomized trial of outpatient cardiac monitoring after cryptogenic. Stroke. Stroke. 2013, 44:528-530. 10.1161/STROKEAHA.112.679100

25. Baturova MA, Sheldon SH, Carlson J, et al.: Electrocardiographic and Echocardiographic predictors of paroxysmal atrial fibrillation detected after ischemic stroke. BMC Cardiovasc Disord. 2016, 16:209. 10.1186/s12872-016-0384-2

26. Halcox JPJ, Wareham K, Cardew A, Gilmore M, Barry JP, Phillips C, Gravenor MB: Assessment of remote heart rhythm sampling using the alivecor heart monitor to screen for atrial fibrillation. Circulation. 2017, 136:1784-1794. 10.1161/CIRCULATIONAHA.117.030583

27. Reed MJ, Grubb NR, Lang CC, Gray AJ, Simpson K, MacRaild A, Weir CJ: Diagnostic yield of an ambulatory patch monitor in patients with unexplained syncope after initial evaluation in the emergency department: the PATCH-ED study. Emerg Med J. 2018, 35:477-485. 10.1136/emermed-2018-207570

28. Pradhan S, Robinson JA, Shivapour JK, Snyder CS: Ambulatory arrhythmia detection with ZIO ${ }^{\circledR}$ XT Patch in pediatric patients: a comparison of devices. Pediatr Cardiol. 2019, 40:921-924. 10.1007/s00246-019-02089-0

29. Turakhia MP, Hoang DD, Zimetbaum P, et al.: Diagnostic utility of a novel leadless arrhythmia monitoring device. Am J Cardiol. 2013, 112:520-524. 10.1016/j.amjcard.2013.04.017

30. Steinhubl SR, Waalen J, Edwards AM, et al.: Effect of a home-based wearable continuous ECG monitoring patch on detection of undiagnosed atrial fibrillation: the mSToPS randomized clinical trial. JAMA. 2018, 320:146-155. 10.1001/jama.2018.8102

31. Kaura A, Sztriha L, Chan FK, Aeron-Thomas J, Gall N, Piechowski-Jozwiak B, Teo JT: Early prolonged ambulatory cardiac monitoring in stroke (EPACS): an open-label randomised controlled trial. Eur J Med Res. 2019, 24:25. 10.1186/s40001-019-0383-8

32. Brignole M, Moya A, de Lange FJ, et al.: 2018 ESC guidelines for the diagnosis and management of syncope. Eur Heart J. 2018, 39:1883-1948. 10.1093/eurheartj/ehy037

33. Arnold R, Layton A: Cost analysis and clinical outcomes of ambulatory care monitoring in medicare patients: describing the diagnostic odyssey. JHEOR. 2015, 2:161-169. 10.36469/9897

34. Barrett PM, Komatireddy R, Haaser S, et al.: Comparison of 24-hour Holter monitoring with 14-day novel adhesive patch electrocardiographic monitoring. Am J Med. 2014, 127:95. 10.1016/j.amjmed.2013.10.003 